\title{
Human Gene Patents and the Question of Liberal Morality
}

\author{
THEO PAPAIOANNOU ${ }^{1}$
}

\begin{abstract}
Since the establishment of the Human Genome Project and the identification of genes in human DNA that play a role in human diseases and disorders, a long, moral and political, battle has began over the extension of IPRs to information contained in human genetic material. According to the Nuffield Council on Bioethics, over the past 20 years, large numbers of human genes have been the subject of thousands of patent applications. This paper examines whether human gene patents can be justified in terms of liberal theories of morality such as natural law, personality development, just reward and social utility. It is argued that human gene patents are in conflict with fundamental principles of liberal morality and justice because they result in "genetic information feudalism".
\end{abstract}

\section{Introduction}

In the literature of Intellectual Property Rights (IPRs), patenting is considered to be a statutory and moral way of increasing innovations and boosting technological development. ${ }^{2}$ For this reason, individual rights to patents have been extended to almost all knowledge-intensive sectors, including health care. For instance, in recent years, there have been a number of legislative attempts to protect human genetic materials. Among them are the EU Directive on the Legal Protection of Biotechnology Inventions in 1998 and the subsequent United Kingdom (UK) law via the Patent Regulations in 2000.

This paper draws on my recent critique of the moral foundations of IPRs ${ }^{3}$ in order to address the following question: can human gene patents be justified in terms of liberal theories of morality ${ }^{4}$ ? The latter include the theories of natural law, personality development, just reward and social utility. The argument of this paper is that extension of IPRs such as patents to human genetic materials is not morally defensible. Human gene patents are in conflict with fundamental principles of liberal morality and justice. In fact, these principles are sacrificed for the sake of "genetic information feudalism".

The argument is structured as follows: The first section focuses on liberal theories of morality and IPRs; next, I examine the case of human gene patents; and I conclude that IPRs are morally indefensible. 


\section{Liberal Theories of Morality and IPRs}

\section{Natural Law}

The first liberal attempt to justify IPRs morally is in terms of the natural law theory. Specifically, it is stated that IPRs are moral-claim rights that each individual has naturally, independently of the laws of government. ${ }^{5}$

The moral justification of IPRs on the grounds of natural law derives from Locke's theory of private property. As is well known in his Second Treatise of Government, Locke introduces the principle of self-ownership as a natural right of each individual to her own person and labour. ${ }^{6}$ Owning herself, each person is free to do with her powers whatever she chooses so long as she does not cause or threaten harm to nonconsenting others. ${ }^{7}$ On the grounds of self-ownership, Locke forms his mixing labour theory that justifies private property as a natural right. According to him: "The Labour of [Man's] Body and the Work of his Hands, we may say, are properly his.

Whatsoever then he removes out of the State that Nature hath provided, and left it in he hath mixed his Labour with, and joyned to it something that is his own, and thereby makes it his Property". 8

Locke's theory of private property is theologically founded. Locke believes that God gave the world to human beings in common and provided them with reason to make use of it to the best advantage of their life. ${ }^{9}$ This theological position leads to the theoretical development of two provisos. The first is the "enough and as good" proviso: private appropriation is morally justified only if it leaves enough and as good to newcomers. The second is the "no waste" proviso: privately appropriated resources must be used, otherwise they become common again. ${ }^{10}$ Both provisos create limits to individual property rights and develop presuppositions of social reproduction.

In the liberal tradition of thought, writers such as Hughes appear to believe that the conception of IPRs as moral-claim rights founded upon self-ownership is theoretically sustainable. ${ }^{11}$ Hughes's defence of IPRs is based on three propositions: first, that production of intangible resources (eg, non-physical recourses), such as ideas, knowledge and information requires a person's labour; second, that these recourses are appropriated from a "common" which is not significantly devaluated by their removal; and third, that intangible recourses can be appropriated without violating the "enough and as good" and "non-waste" provisos. ${ }^{12}$ The question, of course, is whether these propositions hold true? Can the Lockean provisos be applied in IPRs?

Let us begin with Hughes's first proposition that production of intangible resources requires a person's labour. This proposition is above all individualistic. As Richards ${ }^{13}$ points out, ideas, but also knowledge and information, are the result of social rather than individual creation. Indeed, a person's labour in creating these intangible resources has to be conceived as intellectual labour based on interactive learning within society. It is not really meaningful to say that it is the specific person who is the individual creator of intangible resources. As has been argued elsewhere ${ }^{14}$, each person lives because scarcity is inescapable and she lives in society because she 
cannot by herself deal with certain aspects of her scarcity. Knowledge and information as such are important aspects of each person's scarcity. The problem can only be resolved through the contribution of society as a whole. This contribution does not only consist of the relational context of social interaction but also of tangibles resources. For instance, it is well known that several drugs for HIV/AIDS treatments were originally developed with the help of pubic funds in the United States. ${ }^{15}$ In this sense, every person ought to have free access to knowledge and information. Hughes's interpretation of Locke is rather anachronistic ${ }^{16}$ and fails to advance a convincing argument about the relevance of the mixing-labour theory for the moral justification of IPRs. ${ }^{17}$

The problem of anachronism is also apparent in Hughes' second proposition that intangible resources are held in common until some individuals legitimately appropriate them. ${ }^{18}$ This proposition is problematical. In fact, ideas, knowledge and information are neither developed outside of society nor are somehow distributed to all human beings in common until some individuals mix their labour with them. There are not ideas, knowledge and information commons in the sense that Locke intended by "commons". The world does not come furnished with ideas, knowledge and information objects that can be readily appropriated the way an apple can be picked from a tree. ${ }^{19}$ Ideas, knowledge and information are produced with the contribution of society as a whole but become alienated under the capitalist social structure of private property. ${ }^{20}$ Classical liberal theories abstract from this fundamental contradiction of capitalism, due to their individualism.

Now let us examine Hughes's third proposition on the Lockean provisos. Is it plausible to maintain that private appropriation of intangible resources (non-physical property) leaves "enough and as good" to other individuals and satisfies the "no waste" proviso? Hughes thinks that as long as there is a growing common of ideas, knowledge and information everyone has an opportunity to make appropriation. ${ }^{21}$ Therefore, in his view, both provisos are satisfied. Hughes's view is again unconvincing. Even if there were a growing common of intangible resources and even if each individual could make appropriation, this would not always be according to her preferences and thus the principle of self-ownership would be violated. For instance, some individuals might appropriate unique or basic scientific-ideas, knowledge and information, and thereby cause or threaten harm to non-consenting others. $^{22}$

IPRs also violate the "no waste" proviso. This proviso states that private appropriation of new and valuable intangible resources via patents ought not to involve waste. Although Hughes ${ }^{23}$ dismisses the "no waste" proviso as irrelevant, Richards ${ }^{24}$ correctly argues that "The history of patents is rife with example of cases where new ideas and innovations have been delayed or permanently lost by interests who used patents to prolong their existing intellectual and physical capital stock".

Certainly, in the Lockean spirit of thought, one can find more sophisticated arguments than those of Hughes. For instance, Moore ${ }^{25}$ provides a Lockean theory of IP, interpreting the "enough and as good" proviso as a version of weak Pareto- 
superiority. According to him, "The proviso permits individuals to better themselves so long as no one is worsened (weak Pareto-superiority) [...] If no one is harmed by an acquisition and one person is bettered then the acquisition ought to be permitted". ${ }^{26}$ Moore seems to follow Nozick's path ${ }^{27}$ in trying to reformulate the Lockean proviso. As has been argued elsewhere, ${ }^{28}$ the application of this Paretian version of "enough and as good" proviso in IP may work in some cases. "For instance, the appropriation of a "non-extraordinary" idea (i.e. an idea that is neither basic nor unique) may not worsen the situation of anyone, leaving 'enough and as good' 'non-extraordinary' ideas for everyone". ${ }^{29}$ However, in some other cases, as Himma points out, " it is not entirely clear [...] that IP protection does not make others worse off than they would have been. If A discovers the only possible cure for cancer and perversely decides to withhold it from everyone with cancer, the cancer patients seem worse off in the following sense: they had a positive chance of survival prior to A's exclusive appropriation since, after all, someone else might have discovered it and made it freely available; now this chance is denied them". ${ }^{30}$

Himma, ${ }^{31}$ through his critical approach to Locke's theory, provides a different justification for IP. Specifically, he stresses that there are two interpretations of Locke's argument of original acquisition of property. One interpretation emphasises the mixing-labour theory while the other focuses on improvement and creation of value through labour. However, Himma notes that both interpretations of Locke's argument depend on the assumption that we causally interact with pre-existing material objects. This assumption does not apply to intellectual content. Himma argues that knowledge and information are abstract objects with which we cannot causally interact. Thus, as he puts it, "If I cannot causally interact with abstract objects, then I can neither mix my labour with an abstract object nor use my labour to create new value by improving some existing abstract intellectual object". ${ }^{32}$ For Himma, the Lockean argument has to be modified in order to apply to intellectual objects. Thus, he suggests a justification of protection of intellectual property on the grounds of strong interests of creators in the intangible resources they create and in the time and effort they expend in creating them.

Although Himma may be right in stressing the problems of application of the Lockean argument to intellectual objects, he is rather incorrect in believing that the strong interests of creators provide moral justification for protecting intellectual property. There is no moral reason why a creator, who has stronger interests than others in specific intangible recourses, should have the right to exclusive use of these recourses. The fact that a creator has stronger interests than others in specific intangible resources does not imply that others have no interests at all in these resources. Why is it that those creators' interests can only be morally served through IP and not through something else, say, for instance, recognition for their achievements in community? Are creators' interests in intangible resources only material interests? What about creators like, for instance, those involved in Open Source and Synthetic Biology? Isn't the case that Open Source and Synthetic Biology ${ }^{33}$ creators expend time, energy and labour but believe that their interests ought not to be served through their exclusive use of ideas, knowledge and information? Are these creators "....in need of medical or psychological treatment"? ${ }^{34}$ 


\section{Personality Development}

The second liberal attempt to justify IPRs is in terms of the theory of personality development. In this attempt, IPRs constitute a moral necessity for the development of each individual's personality. ${ }^{35}$ The latter can only be adequately expressed in ethical community. That is a liberal realm in which free contracts and free exchange take place. IPRs are thought to be moral rights because they facilitate the development of each individual's personality in ethical community.

The moral justification of IPRs in terms of personality development derives from Hegel's theory of property. In his Philosophy of Right, Hegel conceives private property as an abstract right related to human needs and freedom. ${ }^{36} \mathrm{He}$ insists that, in order to satisfy their physical needs and develop their individuality and freedom, people need to have control of resources. In Hegel's theory, freedom is conceived as each individual's ability to form abstract thoughts and to relate them to particular needs and desires. ${ }^{37}$ Personality is viewed as a part of the inner subjective world of each individual. Hegel stresses that both freedom and personality must be translated into the external objective world by means of private property. In his theory, the individual who owns an object is able to abstract herself in thought from any particular need and to embody her free will and personality into that object. Denial of this personal link to an object results in alienation. ${ }^{38}$

Hegel's concept of alienation plays a key role in his justification of private property. Hegel thinks that those individuals, who are alienated from their property or those who are propertyless, fail to get recognition as persons in community. In his thought, only property owners can be recognised as persons entering into free contractual relationships. ${ }^{39}$ Hegel's concept of ethical community refers to the liberal market place as one moment of ethical life. That is the specific social context rooted to custom and tradition of the ancient city-states. ${ }^{40}$ Property in this context is not absolute (unlimited) but is legally constrained by the laws of ethical community. ${ }^{41}$

The question is whether justification of IPRs as a necessity for personality development can be theoretically sustained. Hegel's answer is clear: creators are the legitimate owners of their intellectual products. He also argues that "Single products of my particular and mental skill and of my power to act I can alienate to someone else and I can give him the use of my abilities for restricted period, because, on the strength of this restriction, my abilities acquire external relation to the totality and universality of my being". ${ }^{42}$ This argument aims to resolve the problem of IP exchange. For Hegel, such exchange is possible because it does not necessarily alienate the creator from the "universal ways and means of multiplying [...] books and machines". 43

As has been argued elsewhere, ${ }^{44}$ the Hegelian justification of IPRs is quite problematical. First of all, the personality argument fails with regard to epistemology. As Hughes says, personality is manifested to varying degrees in different objects. We might assume that a person who writes a poem expresses a different degree of personality from a person who writes a scientific paper because the latter is more 
neutral (or less personal) than the former. But how do we know that one IP creation (say, in poetry) embodies more personality than another (IP creation in poetry)? Should more personality embodied in IP imply more protection of IP? What about those IP products which express little or no personality of their creators? ${ }^{45}$ Does, after all, ownership of one's personality also translate into ownership of the expressions of personality? ${ }^{46}$

The second aspect in which the Hegelian justification of IPRs fails is that of social recognition. At this point, a number of questions can be also raised. What is social recognition and how does it come about? Can social recognition only be expressed through private property rights? Is Hughes right to argue that recognition follows from payments made to the property creator? ${ }^{47}$ Or, is Richards right to point out that recognition comes, for instance, through publications in journals and in other media which provide no direct compensation to their creators? ${ }^{48}$ It might be said that both Hughes and Richards are incorrect in their views of social recognition. IP creators might receive direct compensation for their time and energy or they might publish extensively but still they might not be socially recognised. The reason for this is that social recognition rather depends on whether essential social needs are satisfied. IP can only satisfy commercial needs generated within the capitalist market, taking the form of individual needs. Essential needs outside the market realm remain unsatisfied. These needs include the development of presuppositions of social reproduction.

\section{Just Reward}

The third attempt to justify IPRs morally is in terms of the theory of just reward. According to this theory, IPRs constitute a just reward for enterprise and merit. Individual creators of intangible resources such as innovators and inventors morally deserve to be rewarded for their qualities and talents.

The moral justification of IPRs on the grounds of just reward mainly derives from libertarianism. ${ }^{49}$ Libertarians ${ }^{50}$ defend principles of justice which require that each individual is entitled to her talents and abilities. Whatever goods are acquired on the basis of natural talents and abilities are considered to be just. Libertarians argue that just distribution results from people's free exchanges. ${ }^{51}$ For instance, Nozick advances an "entitlement theory of justice" based on three distributive principles:

"1. A person who acquires a holding in accordance with the principle of justice in acquisition is entitled to that holding.

2. A person who acquires a holding in accordance with the principle of justice in transfer, from someone else entitled to the holding, is entitled to the holding.

3. No one is entitled to a holding except by (repeated) applications of I and 2."

Nozick's entitlement theory of justice can be translated as follows: if I own an intangible resource, then principle 1 tells us how the resource came to be owned; principle 2 says that I am free to transfer my intangible resource as I wish; principle 3 tells us what to do in the case of violation of principles 1 and 2. Nozick's entitlement theory implies that if people's current intangible resources are justly acquired (eg, if 
they are not stolen from others), then just distribution can only take place in the free market. People have the right to sell and buy ideas, knowledge and information, benefiting from free exchange. The state is not morally justified to intervene in order to redistribute the benefits of these intangible resources to naturally disadvantaged or less creative people. Only the owners of intangible resources can decide on such redistribution. In order to illustrate his position, Nozick explicitly uses the example of a person who "finds a new substance in an out-of-the way place. He discovers that it effectively treats a certain disease and appropriates the total supply". Nozick clearly justifies this appropriation on two grounds: first, on the grounds of self-ownership (eg, the person does not steal from others but uses his own talents and abilities) and second, on the grounds of reformulated Lockean proviso (eg, the person does not worsen the situation of others). ${ }^{53}$

It might be said that Nozick's meritocratic arguments are problematical. First of all, as Kymlicka points out, "the intuitive argument ignores our intuition about dealing fairly with unequal circumstances". 54 The principle of fairness is a "self-evident" truth that requires social redistribution to remedy unequal circumstances developed in the process of exchange. Second, the self-ownership argument fails to take account of the socio-economic presuppositions of natural talents and abilities. The latter remain natural potentialities if individuals lack the economic and social means of their development. ${ }^{55}$ Nozick's self-ownership argument is implicitly founded upon a genetic determinism $^{56}$ that, as Barry would say, is simply an expression of his ignorance. $^{57}$

\section{$\underline{\text { Social Welfare }}$}

All the liberal attempts to justify IPRs that we have discussed so far are predominantly deontological. This means that they are in competition with utilitarianism. The latter is a consequentialist theory of morality that holds that legal rules such as IPRs are justified to the extent that they promote happiness in society. ${ }^{58}$ Certainly, there are many different versions of utilitarianism: hedonistic act utilitarianism, welfarist act utilitarianism, preference act utilitarianism, economic efficiency act utilitarianism, rule utilitarianism, etc. Utilitarianism, especially in its hedonistic version formulated by Bentham ${ }^{59}$ and Mill, ${ }^{60}$ conceives happiness as a sum of pleasures. "Pleasure is good and pain or displeasure is bad". ${ }^{61}$ Utilitarianism is a goal-based theory concerned with the social welfare of each individual in so far as this contributes to a particular conception of the good. ${ }^{62}$ Therefore, this theory is in contradistinction with right-based theories such as natural law, personality development and reward-based theories of IPRs.

Although it is true that the link between happiness and well-being has not been yet established in moral philosophy, ${ }^{63}$ it is also true that utilitarianism provides the most popular arguments in defence of IPRs. Thus, as Moore observes, "Beginning with the first Patent Act of 1790 and continuing through the adoption of Berne Convention standards in 1989, the basis given for Anglo-American systems of intellectual property is utilitarian in nature and not grounded in the natural rights of the author or inventor". ${ }^{64}$ IP is considered by utilitarians to be crucial for the development of useful knowledge and innovations which can benefit the public, maximising social 
welfare. ${ }^{65}$ However, critics of utilitarianism object to the conception of IPRs as legal arrangements for maximising social welfare on the grounds that it is instrumental. IPRs are not intrinsically good, critics contend. If IPRs fail the utility test, then, they can no longer be justified in a liberal society. This implies that creators are entitled to their ideas, knowledge and information only in so far as these resources are valued as useful means for maximising social welfare. The interest of society in maximising welfare prevails over the property right of each creator in her intangible resources. Indeed, this is also the main approach of some law and economics theorists such as Posner ${ }^{66}$ to legitimacy: the law is legitimate in so far as it promotes maximisation of welfare and social efficiency. ${ }^{67}$ Certainly, as Himma ${ }^{68}$ observes, there is a variety of law and economics positions on IP. Some theorists attempt to show that protection of IP fails to maximise welfare while some others take a middling position, arguing that some protection of IP is needed to ensure efficiency.

In any case, the moral conflict between deontology and utility has serious political and policy implications. For instance, should government adopt policies which would strengthen IPRs in human genomics to increase economic growth or should it adopt policies which would allow all interested parties in society to have access to DNA sequences so that everyone can come up with new ideas for drugs development? In fact, this is a conflict between justice and utility. ${ }^{69}$ Although there are variations of utilitarianism, almost all of them argue that right actions are useful actions and not just actions. Just actions are right actions to the extent that they are useful actions.

Apart from its instrumental nature and its conflict with deontological theories of justice, utilitarianism also faces the epistemological problem: how can the aggregate welfare produced by IPRs be objectively measured? Moral scepticists clearly dismiss that objective calculation of pleasure and pain can ever be possible. ${ }^{70}$ Happiness or well-being is subjective as it is any particular conception of the good.

\section{The Case of Human Gene Patents}

\section{The Context}

Since the establishment of the Human Genomy Project in 1990 and the identification of genes in human DNA that play a role in human diseases and disorders, a long battle has began over the extension of IPRs to information contained in human genetic material. Human genetic information is clearly an intangible resource and, according to Nuffield Council on Bioethics:

\footnotetext{
"over the past 20 years, large number of genes, section of genes and proteins they produce have been the subject of several thousand patent applications. Many patents have been granted. The identification and cloning of genes that produce therapeutic proteins has led to the development of a number of new medicines based on human proteins whilst the identification of genetic mutations that cause disease has been widely applied in the development of diagnostic tests for relatively rare diseases". 71
} 
The Nuffield Council of Bioethics (NCB) had correctly predicted that with the completion of the sequencing of the human genome, there would be even more increase of patent applications for new medicines and treatments. ${ }^{72}$ Indeed, a recent study by Hopkins et al "Identified a total of 15,603 patent families claiming human DNA sequences published between January 1980 and December 2003. Of these, only one-third $(5,669)$ contain one or more patents granted up to 2005 at one of the three leading patent offices: the USPTO, European Patent Office (EPO) or Japan Patent Office (JPO). Most of this subset (94\%) contains at least one granted US patent, with the numbers rising sharply during the $1990 \mathrm{~s} "{ }^{73}$ The question that arises is whether IPRs over human genomics can be morally justified. Can patents of human genes be morally grounded upon liberal principles of natural law, personality development, just reward and social welfare? There is a need to go on to answer this question because the implausibility of IPRs can only be fully understood within such a specific moral context. To put it another way, the specific example of human gene patents puts our critique of the moral foundations of IPRs in context.

Before answering the question of justifiability of human gene patents, let us briefly examine the current patent legislation. Generally speaking, a patent applicant in Europe has two options: either to apply to the National Patent Office (NPO) of her country or to go to the European Patent Office (EPO) in Munich. As far as the United Kingdom (UK) law is concerned, it is the Patents Act of 1977 that covers both the British and the European systems for granting patents. This Act incorporates the European Patent Convention (EPC) of 1973 and the Community Patent Convention (CPC) of 1975. However, in the particular case of protection of biological materials, it is the European Union (EU) Directive on the Legal Protection of Biotechnological Inventions of 1998 (98/44/EC) that regulates patents. The Directive, which became law in the UK via the Patents Regulation of 2000 (SI 2000, No: 2037), requires biotechnological inventions that meet the granting criteria of novelty, inventiveness and utility be patentable. From legal protectability are excluded the human body and simple discoveries of its elements (eg, the human body and elements which could be used for commercial or industrial purposes), plant and animal varieties (eg, materials which are protected by the International Convention on the Protection of New Plant Varieties) and inventions the exploitation of which would be contrary to morality or ordre public (eg, cloning human beings, modifying the germ line genetic identity of human beings, commercial uses of human embryos, modifying the genetic identity of animals and causing them suffering without substantial benefit to man or animals, etc). ${ }^{74}$

However, it might be argued that the UK patent law makes a problematical distinction: on the one hand, it states that neither the human body nor the simple discovery of a sequence or partial sequence of a gene can be patented; on the other hand it requires that once an element such as a sequence of a gene has been isolated from the human body or produced by a technical process, it can be patented. This reflects an epistemological distinction between scientific knowledge concerning a natural phenomenon (say, genetic information which is encoded in a natural molecule) and scientific knowledge concerning an artificial phenomenon (say, genetic information which is encoded in an artificial molecule). According to the NCB: 


\begin{abstract}
"Patent offices take the view that extracting the genetic information encoded by a DNA sequence is not just a matter of gaining scientific knowledge about a natural phenomenon: it involves the use of cloning techniques to create an artificial molecule in such a way that it includes much the same genetic information as is to be found in the natural phenomenon. And what is held to be important here is that the scientific knowledge concerning the genetic information has been discovered through the creation of the artificial molecule. That is to say, without isolating and cloning a gene it is not possible to identify the sequence of bases of which it is comprised".
\end{abstract}

Certainly, patent offices, by taking this view, aim to demonstrate that genetic information (as to how proteins are to be constructed) encoded in an artificial molecule is not mere "discovery" but "invention" and therefore, according to law, patentable. Nevertheless, it is clear that both forms of scientific knowledge refer to the same information namely, human genetic information. Whether this information is discovered through a natural molecule in the human body (naturally occurred genes) or through the creation of an artificial molecule isolated from the human body (cloned genes) is a matter of the scientific route followed and not a matter of the information as such. Ontologically speaking, in both cases, human genetic information is the same. For this reason, according to the NCB:

"as computational techniques replace cloning as the main route to identifying genes, the issue of the eligibility for patenting of DNA sequences needs to be reopened. The fact that DNA sequences obtained by cloning have in the past been regarded as eligible for patenting does not imply that they should continue to be eligible for patenting when they can be identified from databases constructed by others". 96

Whatever epistemological and ontological problems the current legislation faces, it is clear that human gene patents contain private property claims to different ways of using a DNA sequence. These ways include:

“i) Diagnostic testing. The presence of a faulty gene in an individual can be detected by techniques based on knowledge of the structure of the gene...

ii) Research tools. Since all genes encode parts of biological pathways and systems, knowledge of their DNA sequence can help in the identification of potential targets for which new drugs can be designed and in the development of new vaccines...

iii) Gene therapy. The main aim here is to replace a faulty gene with a normal gene by introducing it into the body. This approach is being pursued in the development of treatment for diseases including cystic fibrosis, various cancers and disorders and the immune system. 
iv) The production of therapeutic proteins to be used as medicines.

Here, a distinctive therapeutic use has been identified for the protein encoded by DNA sequence,

The NCB examines whether granting patents on each of these ways of using a DNA sequence can meet the legal criteria for patenting, ie, novelty, inventiveness and utility. Nevertheless, it does not answer the question of liberal morality: can granting patents on diagnostic testing, research tools, gene therapies, and therapeutic proteins be morally grounded upon principles of natural law, personality development, just reward and social welfare? To answer this question let us consider the moral justification of at least two different ways of using a DNA sequence separately: diagnostic testing and research tools.

\section{Diagnostic Testing}

Diagnostic testing is based on the scientific identification of DNA sequences that are implicated in a disease. ${ }^{78}$ For instance, the identification of the BRCA1 gene located to chromosome 17 is implicated in some forms of breast cancer and for this reason has been used to develop the BRCA1 diagnostic test. In 1995 patents of the BRCAI gene sequence and various mutations were granted to Myriad Genetics, the University of Utah Research Foundation and the US Secretary of Health. These patents give their owners not only monopoly on their diagnostic method, but also the opportunity to prevent others from developing improved diagnostic methods, using the same DNA sequence.

\section{Natural Law}

Can patents of diagnostic tests such as the $B R C A 1$ be morally justified on the grounds of natural law? The answer is negative. First of all, the Lockean principle of selfownership does not apply in the case of $B R C A 1$. The latter is not a sequence that is deliberately created by a scientist who has mixed her labour with an unowned human gene, but a natural phenomenon that already exists. From this it follows that the association between a gene variant and a disease such as breast cancer is not an artificial creation (by anyone who has mixed her labour with a human gene), but a phenomenon that already exists in nature. Therefore, a scientist trying to isolate the $B R C A 1$ gene sequence does not have a justified property claim to that gene sequence. The isolation of a gene from its natural environment or production by means of technical process cannot possibly give rise to a property claim to the isolated gene under a Lockean mixing-labour justification for property because this presupposes the transformation of an isolated (abstract) gene into something valuable (and concrete). Discovery is not a creation of value through labour. In Locke's theory, a person who mixes her labour with an unowned (concrete) object improves that object creating value that did not exist. "Property for Locke is the reward for the conversion or 'improvement' of nature". ${ }^{79}$ Therefore, this theory might justify private property of a diagnostic method but not private property of an isolated gene sequence.

Second, it might be argued that even if the Lockean principle of self-ownership could apply in patents of diagnostic tests such as BRCA1, these would still be morally unjustified because they would violate the proviso of "enough and as good". 
Specifically, the assertion of private property rights over a unique genetic information such as the BRCA1 gene sequence does not leave "enough and as good" to others. As the NCB puts it, "when developing products based on genetic material [...] this concept of inventing around is harder to apply because there may be no alternatives to the naturally occurring DNA sequences". ${ }^{80}$ This worsens the situation of others because it creates fewer chances for them to develop an improved diagnostic test than they would otherwise have if the $B R C A 1$ gene were not patented ${ }^{81}$ Licensing patents of diagnostic tests does not resolve the problem. According to a recent OECD report:

"A survey of the licensing practices of holders of patents that cover diagnosis of genetic disorders showed that almost all the patents were being licensed exclusively; in theory this could allow the monopolisation of genetic testing services.

The cost of exclusively licensed patents is extremely high. This prohibits the provision of genetic testing services, increasing health inequities in a liberal society in which social justice is already marginalised. ${ }^{83}$ For instance, how one would answer the following question? "Whether it is just for only those who can afford genetic services to have access to them, especially since much of the initial research that led to these services was publicly funded?". 84

\section{Personality Development}

Can patents of diagnostic tests such as for $B R C A 1$ be justified on the grounds of moral necessity for personality development? It might be argued that patents of diagnostic tests cannot be morally justified on such grounds because human gene sequences are not intellectual creations expressing the personality of the scientist(s). Scientific knowledge and information are more neutral towards personality and values than other intellectual products. Thus, human gene sequences such as $B R C A 1$ rather express the interaction between biological and environmental factors and their impact on human beings.

On the other hand, patents of diagnostic tests cannot be taken to express the social recognition of the scientist(s) who identified a DNA sequence. Social recognition depends on whether such identification and the subsequent development of diagnostic testing satisfy the social need for better public health. Satisfaction of the social need for better public health does not necessarily presuppose private property and capitalist market.

\section{Just Reward}

Does the scientist(s) who identified a particular human gene sequence implicated in a disease morally deserve to be rewarded with a patent for her enterprise and merit? In response to this question it might be said, first of all, that a scientist is not an abstract individual who lives her life outside society. Therefore, her enterprise and merit are social developments. Libertarian theories of justice such as that of Nozick fail to understand the concept of individual within the context of society. ${ }^{85}$ For this reason, they hide behind their problematical interpretation of Kant's categorical imperative, arguing that any state intervention in private ownership (eg, compulsory license) for the sake of society's benefit is morally wrong. In fact, if one accepts that enterprise 
and merit come about with the contribution of the whole of society, one has also to accept that no scientist(s) deserves to benefit exclusively from them.

\section{$\underline{\text { Social Welfare }}$}

Can patents of human gene sequences morally justified on utilitarian grounds? It might be said that utility is the point at which certain criteria of liberal morality meet certain criteria of legality. Therefore, a human gene patent that is not useful to society or has no industrial application is neither moral nor legal. The obvious question here is the following: Does the granting of patents on DNA sequences such as $B R C A 1$ and subsequently diagnostic testing for diseases like breast cancer maximise social welfare? With respect to this question, one might distinguish between different arguments.

One argument is that, without patents of DNA sequences, the development of new diagnostic tests would be significantly reduced, minimising social welfare. This argument takes account of the significant effort and investment required for testing very large genes or multiple mutations and converting scientific knowledge into clinically reliable diagnostic tests and medicine. Therefore, protection through gene patents is viewed as economic incentive for the development of diagnostic tests, and thereby maximising utility. ${ }^{86}$ It might be said that this view is not entirely convincing. Is private property of genetic information the only economic incentive for the development of diagnostic tests? Is there empirical evidence for the maximisation of social welfare as a consequence of patents of diagnostic tests? The answer to these questions is rather negative. Asserting private property rights over genetic information and subsequent products reduces free competition and increases monopoly in the market. Therefore, it is an illiberal step that minimises social utility.

Another argument with respect to diagnostic tests is that in some areas patents are not even necessary. According to the NCB:

"Many conventional diagnostic tests for a wide range of diseases and disorders have used the presence or absence of other molecules such as proteins as a means of detection. By comparison with medicines, the costs of research and development in the case of diagnostic tests have been relatively low, the time for development relatively short, and the impact of regulation reduced". ${ }^{87}$

Although one might think of maximisation of social welfare as a consequence of the absence of patents, this still has to be empirically verified. Given the epistemological difficulty of measuring social utility objectively, both agreements (for and against human gene patents) lack strong empirical foundation.

\section{Research Tools}

A DNA sequence that has use in research but no immediate therapeutic or diagnostic value is defined as a research tool. According to the NCB: 
"Over the past few years, there has been a marked increase in the number of patents that assert rights over DNA sequences that fall into the category of research tools". ${ }^{8}$

For instance, since 1990s, researchers have extensively used partial DNA sequence or expressed sequence tags (ESTs) as "a shortcut to identifying genes". ${ }^{89}$ Some pharmaceutical companies immediately took the opportunity to fill patent applications in order to secure exclusive rights to the whole genes (whenever these would be identified). Granting patents over parts of genes means that these can be privately owned as research tools, excluding others from research to identify the whole genes. According to Hopkins et al:

"Research tools were the largest component of granted patent portfolios in most pharma and biotech firms, with a majority reporting that more than $60 \%$ of their portfolios had applications in this category". 90

\section{Natural Law}

Can patents on research tools such as ESTs be morally justified on the grounds of natural law? The answer is again negative. ESTs are not intellectual creations of scientists but natural phenomena the discovery of which results in the identification of full-length DNA sequences. Therefore, it cannot be claimed that scientists are morally justified to own ESTs on the grounds of self-ownership. Even if one argued that human genes are unowned information - even if one could mix her labour with these (abstract) information - one could not claim ownership unless she could create something different out of these information. In the case of ESTs and full-length DNA sequences, what we have is scientific discovery, ie, discovery of information that already exists in nature. ${ }^{91}$

It might be said that even if the principle of self-ownership could apply to patents of research tools such as ESTs, these would still violate the Lockean provisos of "enough and as good" and "non-waste". First of all, each EST should be regarded as unique genetic information. ESTs are not abundant in nature. Therefore, the assertion of patent rights over ESTs does not leave "enough and as good" to others. The problem here is that if someone has a patent on a partial DNA sequence or EST, the patent will also extend to the full DNA sequence, even if the full sequence may be isolated by someone else without using the particular EST as a research tool ${ }^{92}$. This results in blocking patents or increased research and transaction costs. According to the OECD, "Even where patent owners are amenable to licensing, the price demanded for use of a genetic invention might pose a barrier to researcher". Second, patenting of partial DNA sequence or ESTs implies patenting of a DNA sequence the function of which is unknown. If for some reason (say, high cost) no new drugs or other research could came out of the patented DNA sequence or ESTs, the "non-waste" proviso would be violated. Indeed, as the OECD stresses, "patents on early 'foundational' discoveries, if not widely licensed, may discourage or limit the use of these important innovations and slow the pace of R\&D in a particular field." 93 
Personality Development

Can patents of research tools such as ESTs be morally justified on the grounds of necessity for personality development? It might be said that, since partial and full DNA sequences are not artificial creations but discoveries, they do not reflect the personality of scientists. In addition to this, patents of research tools such as ESTs do not express social recognition of scientists. The knowledge developed by the use of patented research tools might result in a monopoly of new drugs or other research. This might increase cost and therefore might not satisfy the needs of society for better health welfare and resources.

\section{Just Reward}

Does the scientist(s) who discovered a partial DNA sequence deserve to be rewarded with a patent of research tool for her enterprise and merit? The answer is negative. As has been stressed in the previous case of diagnostic tests, no enterprise and merit come about without the contribution of the whole of society. Therefore, no scientist(s) deserves to benefit exclusively from them.

On the other hand, Kant's categorical imperative can have a different application in the cases of partial and full DNA sequences of humans. For instance, this imperative might not allow patents of research tools: if one accepts that, whether isolated from the human body or not, human genes are ontologically the same, one has to accept that they have to be treated as ends in themselves and not as merely means to utility.

\section{$\underline{\text { Social Welfare }}$}

Are patents of research tools morally justified on the grounds of maximising social welfare? As has been argued throughout this paper, the epistemological problem of utilitarianism limits objective moral judgement. Theoretically, patents on research tools may inhibit social welfare in various ways. According to the NCB, these ways include:

- the cost of research may increase [...]

- research may [...] be made more difficult if researchers are required first to negotiate the use of patented genes and sequences;

- a patent owner may withhold a license to gain maximum financial benefits, or license it exclusively to one or a limited number of licenses;

- companies that wish to acquire the rights to several DNA sequences may decide not to develop a therapeutic protein or diagnostic test because of the number of royalty payments that would be required $[\ldots], 94$

Although the NCB recognises that there is no sufficient empirical evidence to support all the above statements, there are cases in which social welfare is dramatically minimised and which, therefore, need to be avoided. One of those is the case of the CCR5 receptor. According to the NCB:

"In February 2000, Human Genome Sciences Inc (HGS), a US company, was granted a US patent which asserted rights over the 
gene that codes for CCR 5 receptor. The CCR 5 receptor is the route by which the HIVIAIDS virus enters a cell. When HGS originally isolated the gene for this receptor and filed the for the patent in June 1995 [...] they were unaware of the receptor's role in HIVIAIDS [...]. Subsequently the role of CCR 5 receptor was revealed by other researchers, six months after HGS filed its patent application. Another researcher, Dr M Parmentier, had isolated the gene some years earlier but only filed a patent application in March 1996 [...]. Parmentier's patent has not yet been granted". ${ }^{95}$

In order to avoid a case such as that of the CCR5 receptor, the NCB discourages patents which assert rights over DNA sequences as research tools. For the same reason, Cornish et al recommend that the Department of Health "should not adopt a hard and fast rule regarding the patentability of research tools". 96

\section{Conclusion}

This paper has examined the moral justifications of IPRs, taking a closer look at the case of human gene patents. Theoretically, IPRs cannot be sustained as liberal moral rights. On the one hand, they cannot be justified on the grounds of Locke's theory of property because the application of "no waste" and "enough and as good" provisos in the private appropriation of intangible resources is problematical. On the other hand, IPRs cannot be justified as a necessity for personality development because the Hegelian approach to IP leaves open the epistemological question of personality embodiment in IP products and fails to resolve the problem of social recognition of IP creators. Also, IPRs can neither constitute just reward for enterprise nor merit. Individual inventors do not morally deserve to be rewarded for their natural qualities and talents. Finally, IPRs might fail the universal test of social utility. Therefore, utilitarianism does not necessarily justify IPRs.

The implausibility of IPRs is strongly reflected in the case of human gene patents. First of all, patents of diagnostic tests and research tools cannot be morally justified because DNA sequences are natural phenomena and not creations of human labour which can be privately owned. In addition to this, the Lockean provisos of "no-waste" and "enough and as good" cannot justify patents because these do not leave alternatives to the naturally occurring DNA sequences. Second, patents of human genes cannot be justified on the grounds of personality development. Since DNA sequences are natural phenomena and not artificial creations, they reflect interactions between biological and environmental factors and not personality. Third, scientists who identify human gene sequences do not morally deserve to benefit exclusively for their enterprise and merit. The latter come about with the contribution of society as a whole. Fourth, patents of human gene sequences are not always justified on utilitarian grounds. The problem here is that patents of diagnostic tests and research tools do not always maximise social welfare. To make things worst, utility is epistemologically difficult to be measured.

As has been stressed elsewhere, ${ }^{97}$ IPRs are rather political developments which aim to reproduce the capitalist division of knowledge and labour. In this sense, it can be concluded that their extension to genomics is not morally defensible. It constitutes a 
political decision that, in fact, sacrifices liberal morality on the altar of genetic information feudalism. According to Drahos and Braithwaite:

"The redistribution of property rights in the case of information feudalism involves a transfer of knowledge assets from intellectual commons into private hands [...] The effect of this [...] is to raise levels of private monopolistic power to dangerous global heights, at a time when states, which have been weakened by the forces of globalisation, have less capacity to protect their citizens from consequences of the exercise of this power". ${ }^{98}$

In the case of human gene patents, information feudalism involves a transfer of human genetic knowledge from the "common heritage of humanity" hands.

In essence, genetic information feudalism is nothing but another antinomy of capitalism through which the division of knowledge and labour are reproduced as genetically and socially founded class divisions ${ }^{100}$ between individuals and between nation states. This antinomy not only threatens equality but also liberty and human welfare. IPRs violate scientists' right of freedom to research and improvement of the human condition.

\footnotetext{
${ }^{1}$ ESRC Innogen Centre and Development Policy and Practice, The Open University, Milton Keynes, UK t.papaioannou@open.ac.uk

${ }^{2}$ When the phrase "IPRs" is used in this article, it mainly (but not only) refers to patents. Generally speaking, IPRs also include copyrights, trademarks and trade secrets.

${ }^{3}$ T. Papaioannou. Towards a Critique of the Moral Foundations of Intellectual Property Rights. Global Ethics 2006; 2(1): 67-90.

${ }^{4}$ Liberal theories of morality emphasise the primacy of individual freedom, the importance of private property and the virtue of a government limited by the rule of law.

${ }^{5}$ J. Hughes. The Philosophy of Intellectual Property. The Georgetown Law Journal 1988: 77: 287-366. See also B. Bouckaert. What is Property? Harvard Journal of Law and Public Policy 1990; 13: 275 816.

${ }^{6}$ J. Locke. 1988. Two Treatises of Government ( $3^{\text {rd }}$ ed.). Cambridge: Cambridge University Press: 287.

${ }^{7}$ R.J. Arneson. Lockean Self-Ownership: Towards a Demolition. Political Studies 1991; 39: 36.

${ }^{8}$ Locke, op. cit. note 6, p.288.

${ }^{9}$ Ibid, p. 286

${ }^{10}$ J. Waldron. 1988. The Right to Private Property. Oxford. Clarendon Press: 207.

${ }^{11}$ Papaioannou, op. cit. note 3, p.75.

${ }^{12}$ Hughes, op. cit. note 5, p.300.

${ }^{13}$ D.G. Richards. The Ideology of Intellectual Property Rights in the International Economy. Review of Social Economy 2002; IX (4): 531.

${ }^{14}$ T. Papaioannou. Nozick Re-visited: the Formation of the Right-Based Dimension of his Political Theory. International Political Science Review 2008; 29(3): 261-280.

${ }^{15}$ C. May and S.K. Sell. 2006. Intellectual Property Rights: A Critical History. Colorado and London: Lynne Rienner Publishers, Inc: 3.

${ }^{16}$ The problem of anachronism here means that Hughes fails to provide an interpretation of Locke that is relevant to contemporary analysis of IPRs.

${ }^{17}$ Papaioannou, op. cit. note 3, p.76.

${ }^{18}$ Ibid

${ }^{19}$ This point was made by one of this journal's referees. I am indebted to him/her for the contribution.
} 
${ }^{20}$ K. Marx. 1975. Early Writings. London: Penguin.

${ }^{21}$ Hughes, op. cit. note 5, p.325.

${ }^{22}$ Papaioannou, op. cit. note 3, p.77.

${ }^{23}$ Ibid

${ }^{24}$ Richards, op. cit. note 13, p.532.

${ }^{25}$ A.D. Moore. 2001. Intellectual Property and Information Control: Philosophical Foundations and Contemporary Issues. New Brunswick (USA) and London (UK): Transaction Publishers: 110.

${ }^{26}$ Ibid, p.109

${ }^{27}$ R. Nozick. 1974. Anarchy, State and Utopia. Oxford. Blackwell.

${ }^{28}$ Papaioannou, op. cit. note 3, p.79.

${ }^{29}$ Ibid

${ }^{30}$ K. Himma. 2006. The Justification of Intellectual Property: Contemporary Philosophical Disputes.. Berkeley Center for Law and Technology, Paper 21: 20. Available at:

http://repositories.cdlib.org./bclt/lts/21/

${ }^{31}$ K. Himma. 2005. Justifying Intellectual Property Protection: Why the Interests of Content-Creators Usually Win Over Everyone Else's. Berkeley Center for Law and Technology. Law and Technology Scholarship, Paper 13. Available at: http://repositories.cdlib.org./bclt/lts/13/

32 Ibid, p.4

${ }^{33}$ A. Rai \& J. Boyle. Synthetic Biology: Caught between Property Rights, the Public Domain, and the Commons. PloS Biology 2007; 5(3): e58. Available at:

http://www.plosbiology.org/article/info:doi/10.1371/journal.pbio.0050058

${ }^{34}$ Himma, op. cit. note 30, p.7.

${ }^{35}$ Papaioannou, op. cit. note 3, p.78.

${ }^{36}$ G.W.F. Hegel. 1942. Philosophy of Right. Oxford. Clarendon Press.

${ }^{37}$ Waldron, op. cit. note 10, p.352.

${ }^{38}$ See also Papaioannou, op. cit. note 3, p.78.

${ }^{39}$ Hegel, op. cit. note 36, p.71.

${ }^{40}$ A. Callinicos. 1999. Social Theory: A Historical Introduction. Cambridge. Polity.

${ }^{41}$ C. May. 2000. A Global Political Economy of Intellectual Property Rights. London and New York: Routledge: 26.

${ }^{42}$ Hegel, op. cit. note 36, p.67.

43 Ibid, p.69

${ }^{44}$ Papaioannou, op. cit. note 3, p.79.

${ }^{45}$ Hughes, op. cit. note 5, p.339.

${ }^{46}$ See also Himma, op. cit. note 30, p. 19 .

${ }^{47}$ Ibid, p.49

${ }^{48}$ Richards, op. cit. note 13, p.535.

${ }^{49}$ This does not imply that the principle of just reward is a uniquely libertarian view.

${ }^{50}$ L. Spooner. 1971. A Letter to Scientists and Inventors. In The Collected Works of Lysander Spooner. C. Shively, ed. Weston: M\&S Press; A. Rand. 1967. Capitalism: the Unknown Ideal. New York: New American Library; R. Nozick. 1974. Anarchy State and Utopia. Oxford: Blackwell; J. Narveson. 1988. The Libertarian Idea. Philadelphia: Temple University Press.

${ }^{51}$ W. Kymlicka. 1990. Contemporary Political Philosophy: An Introduction. Oxford: Clarendon Press.

${ }^{52}$ Nozick, op. cit. note 27, p.97.

${ }^{53}$ Ibid, p. 181

${ }^{54}$ Ibid, p. 100

${ }^{55}$ Papaioannou, op. cit. note 14

${ }^{56}$ The term "genetic determinism" refers to Nozick's view of genetically acquired talents and abilities as determinants of each individual's performance in creating and appropriating resources, including intangible resources.

${ }^{57}$ B. Barry. 2005. Why Social Justice Matters. Cambridge: Polity Press.

${ }^{58}$ A. Rayan. 1987. Property. Milton Keynes: Open University Press.

59 J. Bentham. 1970. An Introduction to the principles of Morals and Legislation. In The Collected Works of Jeremy Bentham. J.H. Burns and H.L. Hart, eds. Oxford: Clarendon Press.

${ }^{60}$ J. Mill. 1937. An Essay on Government. Cambridge: Cambridge University Press.

${ }^{61}$ D.D. Raphael. 1994. Moral Philosophy. Oxford: Oxford University Press. 
${ }^{62}$ R. Dworkin. 1977. Taking Rights Seriously. London: Duckworth.

${ }^{63}$ B. Williams. 1972. Morality: An Introduction to Ethics. Cambridge: Cambridge University Press.

${ }^{64}$ Moore, op. cit. note 25, p.37.

${ }^{65}$ A. Rosenberg. On the Priority of Intellectual Property Rights, Especially in Biotechnology. Politics, Philosophy and Economics 2004; 3 (1): 77-95.

${ }^{66}$ R.A. Posner. 1981. The Economics of Justice. Cambridge MA: Harvard University Press.

${ }^{67}$ Ibid, p.4

${ }^{68}$ Himma, op. cit. note 30, p. 13.

${ }^{69}$ Raphael, op. cit. note 61, p.48.

${ }^{70}$ J.L. Mackie. 1997. Ethics: Inventing Right and Wrong. London: Penguin.

${ }^{71}$ Nuffield Council on Bioethics. 2002. The Ethics of Patenting DNA: A Discussion Paper. London: Nuffield Council on Bioethics.

${ }^{72}$ Ibid

${ }^{73}$ M.M. Hopkins et al. DNA Patenting: the End of an Era? Nature Biotechnology 2007; 25(2): 185.

${ }^{74}$ W.R. Cornish, M. Llewelyn \& M. Adcock. 2003. Intellectual Property Rights (IPRs): A Study into the Impact and Management of Intellectual Property Rights within the Healthcare Sector. Cambridge: Public Health Genetics Unit, Genetics Knowledge Park.

${ }^{75}$ Nuffield Council on Bioethics, op. cit. note 71, p.27.

${ }^{76}$ Ibid, p. 28

${ }^{77}$ Ibid, pp.47-48

${ }^{78}$ Ibid, p.48

${ }^{79}$ May, op. cit. note 41, p.24.

${ }^{80}$ Ibid, p.50 (italics added)

${ }^{81}$ Here one can follow Moore (op. cit. note 25, p. 113) in accepting that "The appropriate baseline for determining bettering and worsening with reference to acquisition is the acquisitive case compared to the moment before the acquisition".

${ }^{82}$ OECD. 2002. Genetic Inventions, Intellectual Property Rights and Licensing Practices: Evidence and Policies. Paris: OECD.

${ }^{83}$ Barry, op. cit. note 57.

${ }^{84}$ A. Buchanan et al. 2000. From Chance to Choice: Genetics and Justice. Cambridge: Cambridge University Press.

${ }^{85}$ The libertarian argument cannot be possibly disposed of in this article. For a critique of this argument see further in Papaioannou, op. cit. note 14.

${ }^{86}$ Nuffield Council on Bioethics, op. cit. note 71, p.51.

${ }^{87}$ Ibid, p.52

${ }^{88}$ Ibid, p.56

${ }^{89}$ Ibid, p.32

${ }^{90}$ Hopkins et al, op. cit. note 73 , p.186.

${ }^{91}$ It should be noted that the distinction between scientific discovery and invention is morally significant. Something that already exists in nature cannot be morally claimed as a creation of human labour. Therefore, appropriation of discoveries cannot be justified in the same way as appropriations of inventions.

${ }^{92}$ Nuffield Council on Bioethics, op. cit. note 71, p.58.

${ }^{93}$ OECD, op. cit. note 82, p.14.

${ }^{94}$ Nuffield Council on Bioethics, op. cit. note 71, p.59.

${ }^{95}$ Ibid, p.41

${ }^{96}$ Cornish et al, op. cit. note 74, p.65.

${ }^{97}$ Papaioannou, op. cit. note 3, p.85.

${ }^{98}$ P. Drahos \& J. Braithwaite. 2002. Information Feudalism: Who Owns the Knowledge Economy? Oxford: Oxford University Press: 2.

${ }^{99}$ OECD, op. cit. note 82 , p. 11 .

${ }^{100}$ Genetically and socially founded class divisions refer to divisions founded upon unequal distribution of genetic and social resources. 